\title{
A new hierarchically porous Pd@HSQ monolithic catalyst for Mizoroki-Heck cross-coupling reactions
}

\section{$\operatorname{AUTHOR}(\mathrm{S}):$}

Moitra, Nirmalya; Matsushima, Ayumi; Kamei, Toshiyuki; Kanamori, Kazuyoshi; Ikuhara, Yumi H.; Gao, Xiang; Takeda, Kazuyuki; Zhu, Yang; Nakanishi, Kazuki; Shimada, Toyoshi

\section{CITATION:}

Moitra, Nirmalya ...[et al]. A new hierarchically porous Pd@HSQ monolithic catalyst for Mizoroki-Heck cross-coupling reactions. New Journal of Chemistry 2014, 38(3): 1144-1149

\section{ISSUE DATE:}

2014-01-06

URL:

http://hdl.handle.net/2433/197325

\section{RIGHT:}

This journal is (c) The Royal Society of Chemistry and the Centre National de la Recherche Scientifique 2014.; This is not the published version. Please cite only the published version.; この論文は出版社版でありません。引用の際には出版社版をご確認ご利用くだ さい。 


\section{ARTICLE}

Cite this: DOI: 10.1039/xoxxooooox

Received ooth January 2012, Accepted ooth January 2012

DOI: $10.1039 /$ xoxxooooox

www.rsc.org/

\section{A new hierarchically porous Pd@HSQ monolithic catalyst for Mizoroki-Heck cross-coupling reaction}

\author{
Nirmalya Moitra, ${ }^{a}$ Ayumi Matsushima, ${ }^{b}$ Toshiyuki Kamei, ${ }^{b}$ Kazuyoshi \\ Kanamori, ${ }^{a}{ }^{a}$ Yumi H. Ikuhara, ${ }^{c}$ Xiang Gao, ${ }^{c}$ Kazuyuki Takeda, ${ }^{a}$ Yang Zhu, ${ }^{a}$ \\ Kazuki Nakanishi*a and Toyoshi Shimada*b
}

Pore architecture of catalyst supports is an important factor to facilitate accessibility of reactants to catalytic sites. This holds the key to improving catalytic activities. Amongst various catalytic reactions, supported Pd nanoparticles-catalyzed C-C cross-coupling reactions have been attracting a great deal of attention in the last decade. Although various supports have been examined, applications of hierarchically porous monolithic materials have never been reported, mainly because of difficulties in multistep synthesis of catalysts. We herein report a novel on-site reduction-based methodology to hierarchically porous hydrogen silsesquioxane (HSQ) monoliths for one-step synthesis of Pd nanoparticles-embedded monoliths (Pd@HSQ). Characterizations of these monoliths evidence the on-site reduction, i.e. formation of Pd nanoparticles and conversion of Si-H present in the monolith to Si-O . Fast, quantitative reduction of $\mathrm{Pd}^{2+}$ to $\mathrm{Pd}(0)$ to form supported $\mathrm{Pd}$ nanoparticles is achieved with preservation of the porous structure in the original monolith, which makes this material attractive for a catalyst of C-C cross-coupling reactions. The obtained Pd@HSQ catalyst has been employed for the Mizoroki-Heck cross-coupling reaction. High accessibility of reactant molecules, undetectable leaching of Pd nanoparticles and easy separation of the monolith from liquid media provide high catalytic activity, reusability and easy handling.

\section{Introduction}

The C-C bond formation reactions using Pd catalysts have become a standard repertoire ${ }^{1,2}$ in organic chemistry to synthesize compounds for pharmacological, ${ }^{3-5}$ biological, $^{6}$ or optical $^{7}$ applications. In particular, Pd nanoparticles as a heterogeneous catalyst have been attracting a great deal of attention due to easier separation from reaction systems, which is otherwise difficult when using Pd complexes or salts as homogeneous catalysts. $^{8}$ However, these nanoparticles generally undergo aggregation to form bulky particles in solution, which decreases the surface to volume ratio and results in reduced catalytic activities. ${ }^{9}$ Such aggregation of nanoparticles can be prevented either by using capping agents ${ }^{10}$ or immobilizing them on a solid support, ${ }^{11,12}$ while the latter offers more attractive advantages in higher reusability and recyclability, ${ }^{13}$ which impart a huge impact from environmental and economic points of view. ${ }^{14} \mathrm{~A}$ lot of research have therefore been devoted to engineering supported catalysts to achieve high catalytic activity, facile separation, reusability and recyclability. ${ }^{15-18}$ Periodic mesoporous materials, ${ }^{19-22}$ magnetic nanoparticles $^{23}$ and porous polymers ${ }^{24-26}$ have been studied extensively as the supports. Among all the support morphologies, hierarchically porous monoliths containing welldefined three-dimensionally open macro-mesoporous architecture, which facilitates the transfer of reactant molecules to catalytic sites and easy separation of the catalysts from reaction media, possess a huge potential as the catalyst support. ${ }^{27}$ However, examples of such monolithic materials used as catalysts for C-C coupling reactions are rare. ${ }^{28}$ To the best of our knowledge, only a few reports are known. One of which describes a three-step methodology involving thiol functionalization on hirarchically porous silica prepared via high internal phase emulsion (denoted as Si(HIPE)), followed by introduction of $\mathrm{Pd}^{2+}$ and reduction of it by sodium borohydride $\left(\mathrm{NaBH}_{4}\right)$ to form Pd nanoparticle-immobilized Si(HIPE). ${ }^{28}$ Another report uses ionic liquid to immobilize Pd catalyst on Si(HIPE). ${ }^{29}$ Multistep catalyst synthesis and the use of ionic liquid in these examples, however, limit their applicability.

In synthetic organic chemistry, hydrosilanes have been used as an efficient reducing agent for their hydride donating capacity. $^{30}$ Their potential in reducing noble metal salts, however, has long been overlooked, and only a few reports disclosed their applicability. ${ }^{31-33}$ Very recently, we have reported a synthesis of hierarchically porous hydrogen silsesquioxane monoliths (HSQ) via sol-gel accompanied by phase separation. ${ }^{34}$ We herein show that this solid-state analogue of hydrosilanes can reduce $\mathrm{Pd}^{2+}$ in aqueous media to $\operatorname{Pd}(0)$ via host-guest redox mechanism on the pore surfaces (onsite reduction). Characterizations of the as-synthesized catalystembedded monolith show a clear evidence of on-site reduction and embedment of $\operatorname{Pd}(0)$ nanoparticles confined in the pores.

Applications of this monolith to the Mizoroki-Heck crosscoupling reaction unveil high catalytic activity and easy 
separation of the catalyst. A variety of substrates were examined in order to test the catalytic and substrate tolerances. Furthermore, high enough reusability of the catalyst was confirmed without decreasing the catalytic activity. These features are made possible by facile access of reactant molecules to catalytic sites, easy separation from the system, and undetectable leaching of Pd nanoparticles.

\section{Results and discussion \\ HSQ monolith as the host}

As reported previously, ${ }^{34}$ the hierarchically macro-mesoporous HSQ monolith was prepared by a dilute acid-catalyzed sol-gel reaction of trimethoxysilane (HTMS) accompanied by phase separation under the presence of poly(ethylene oxide) (PEO). The acidic condition is advantageous to preserving the reactive $\mathrm{Si}-\mathrm{H}$ groups as described later, and a change in the concentration of PEO in the sol-gel system results in controlled phase separation tendency, i.e. controlled size of macroporous structures. A scanning electron micrograph of a dried monolith used in this study shows the presence of the macroporous cocontinuous structure (Fig. S1a, ESI $\dagger$ ). The high connectivity of macropores is critical for the facilitation of fluid transport, and this kind of monolith is already applied to separation media. ${ }^{35,36}$ A sharp size distribution of macropores with a most probable size of $1.6 \mu \mathrm{m}$ was confirmed by mercury porosimetry (Fig. S1b, ESI $\dagger$ ). Mesopores ( $<2 \mathrm{~nm}$, including “micropores") in the macropore skeletons were characterized by nitrogen adsorptiondesorption measurements (Fig. S1c, ESI $\dagger$ ). These small pores contribute to high specific surface area $\left(800 \mathrm{~m}^{2} / \mathrm{g}\right)$ of the HSQ monolith. The significance of the HSQ monolith lies in the complete preservation of reactive $\mathrm{Si}-\mathrm{H}$ bonds as evidenced by ${ }^{29} \mathrm{Si}$ solid-state NMR (Fig. S1d, ESI $\dagger$ ). The NMR spectrum mostly consists of $\mathrm{T}^{3}$ with only a small amount of $\mathrm{T}^{2}\left(\mathrm{~T}^{n}\right.$ stands for the silicon species with $\mathrm{HSi}(\mathrm{OSi})_{n} \mathrm{X}_{3-n}$, where $\mathrm{X}=\mathrm{OH}$ or $\mathrm{OCH}_{3}$, representative structures shown in Fig. 2e), and no Q species $\left(\mathrm{SiX}_{4}\right.$, where $\mathrm{X}=\mathrm{OSi}, \mathrm{OH}$ or $\left.\mathrm{OCH}_{3}\right)$ are found. These abundant $\mathrm{Si}-\mathrm{H}$ groups on the pore surface can be used for reduction of $\mathrm{Pd}^{2+}$. Furthermore, the ratio of $\mathrm{T}^{3}$ in the original monolith is sufficiently high (87\%, corresponds to $96 \%$ corosslinking density), which promises mechanical stability of this material.

\section{Host-guest redox for Pd@HSQ synthesis}

The obtained HSQ monolith with the preserved Si-H moieties was subjected to reduction of $\mathrm{Pd} 2+\left(\right.$ as $\left.\mathrm{PdCl}_{2}\right)$ to $\mathrm{Pd}(0)$ by immersing the monolith in an aqueous solution containing a desired concentration of $\mathrm{PdCl}_{2}$. An instant color change in the monolith and hydrogen evolution indicates the successful proceeding of on-site reduction. The oxidation of $\mathrm{Si}-\mathrm{H}$ to $\mathrm{Si}-\mathrm{O} \sim$ occurs simultaneously with reduction of $\mathrm{Pd}^{2+}$ and hydrogen formation (Eq. 1 and Fig. S2, ESI†).

$2 \mathrm{O}_{1.5} \mathrm{Si}-\mathrm{H}+\mathrm{Pd}^{2+}+2 \mathrm{H}_{2} \mathrm{O} \rightarrow 2 \mathrm{O}_{1.5} \mathrm{Si}-\mathrm{OH}+\mathrm{Pd}(0)+\mathrm{H}_{2}+2 \mathrm{H}^{+}$ ......... (1)

Termination of the reaction after $3 \mathrm{~h}$ was assumed by a disappearance of the solution color and the end of the hydrogen evolution (Figs. 1b and c). This monolith obtained through the reduction of $\mathrm{Pd}^{2+}$ will be referred hereafter as Pd@HSQ. Even after the reduction, preservation of macroporous co-continuous structure, which is important for fast transfer of reactants, was revealed by the SEM image of Pd@HSQ (Fig. 2a). The formation of $\mathrm{Pd}(0)$ particles is confirmed by XRD by an appearance of sharp peaks corresponding to metallic $\operatorname{Pd}(0)$ (Fig. 2b). An average particle size of $20 \mathrm{~nm}$ was deduced from the XRD by applying the Scherrer equation. Although specific

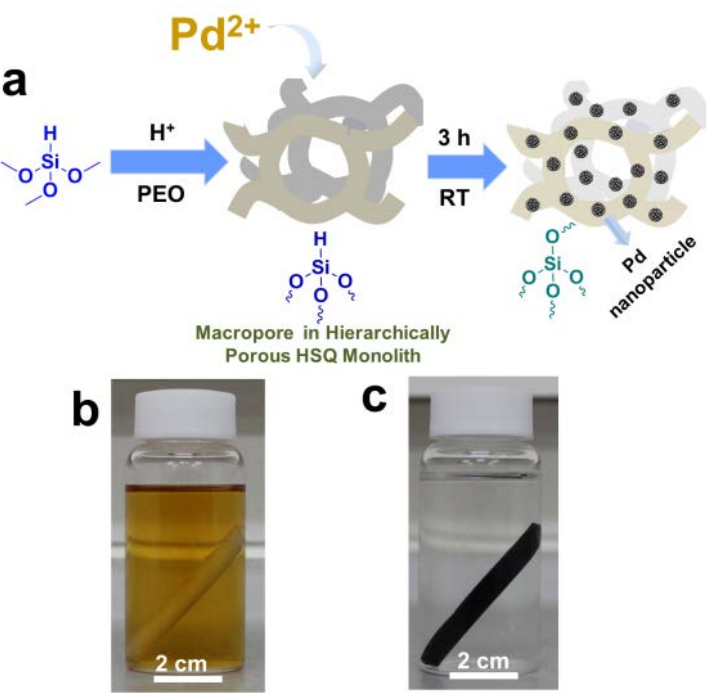

Fig. 1 (a) Schematic representation of on-site reduction of $\mathrm{PdCl}_{2}$ on HSQ monolith; simultaneous transformation of $\mathrm{Pd}^{2+}$ to $\mathrm{Pd}(0)$ nanoparticles and $\mathrm{Si}-\mathrm{H}$ to $\mathrm{Si}-\mathrm{O} \sim$. (b,c) Digital camera images of the HSQ monolith right after immersed in $\mathrm{PdCl}_{2}$ solution and after reacted for $3 \mathrm{~h}$, respectively.
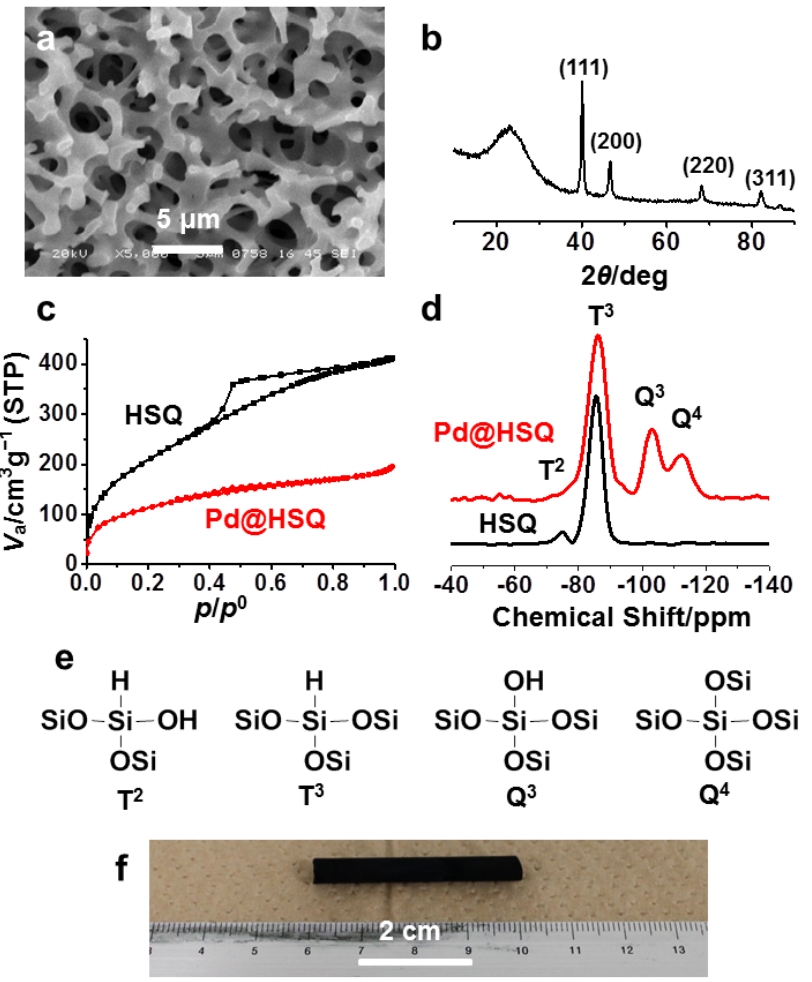

Fig. 2 Characterizations of the obtained Pd@HSQ monolith. (a) SEM image of Pd@HSQ, showing the preservation of macroporous co-continuous structure after on-site reduction. (b) XRD pattern after the on-site reduction, showing the presence of $\operatorname{Pd}(0)$ by its corresponding Bragg diffractions. (c) Nitrogen adsorption-desorption isotherms, showing the decreases in specific surface area (800 to $420 \mathrm{~m}^{2} \mathrm{~g}^{-1}$ ) from HSQ to Pd@HSQ. (d) Another evidence of the on-site reduction by ${ }^{29} \mathrm{Si}$ solid-state NMR, showing the appearances of $\mathrm{Q}^{3}$ and $\mathrm{Q}^{4}$ signals in Pd@HSQ due to transformation of $\mathrm{O}_{1.5} \mathrm{Si}-\mathrm{H}$ to $\mathrm{O}_{1.5} \mathrm{Si}-\mathrm{OH}$ and $\mathrm{O}_{1.5} \mathrm{Si}-\mathrm{O}-\mathrm{SiO}_{1.5}$ moieties. (e) Schematic representation of $\mathrm{T}$ 
and Q centers comprising HSQ and Pd@HSQ. (f) Digital camera image of the as-dried Pd@HSQ monolith.
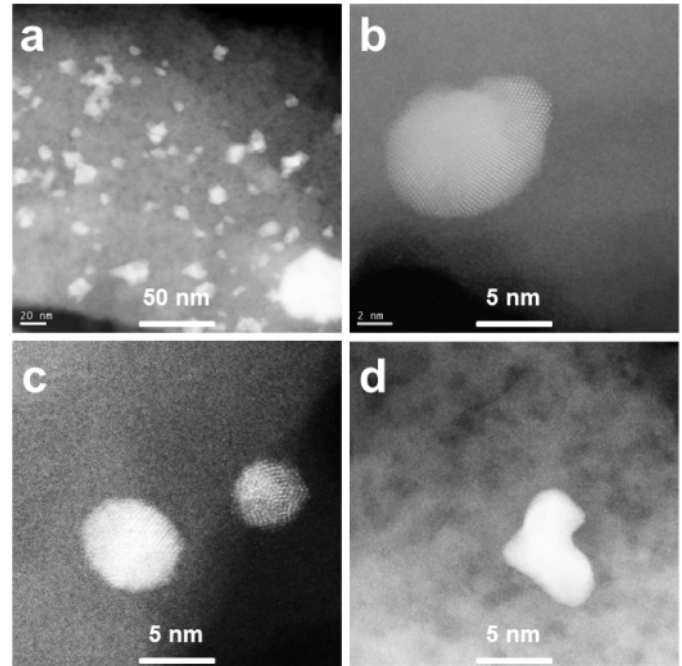

Fig. 3 Characterizations of Pd(0) nanoparticles in Pd@HSQ by HAADF-STEM. (a) Low-magnification image showing the presence of nanoparticles embedded in the macropore skeletons of the HSQ monolith. (b,c,d) Small nanoparticles confined in the meso- and micropores of the Pd@HSQ monolith.

surface area and pore size decreased in Pd@HSQ (Fig. 2c) because of partial blocking of meso- and micropores by asformed Pd nanoparticles, the decreases are not detrimental to applications to catalysts as shown later. The oxidation of $\mathrm{Si}-\mathrm{H}$ to $\mathrm{Si}-\mathrm{O} \sim$ can be confirmed using ${ }^{29} \mathrm{Si}$ solid-state NMR on Pd@HSQ by an appearance of the Q signals (Fig. 2d). A disappearance of $\mathrm{T}^{2}$ and a decrease in $\mathrm{T}^{3}(87$ to $61 \%)$ with an appearance of $\mathrm{Q}^{3}(22 \%)$ and $\mathrm{Q}^{4}(17 \%)$ because of the oxidation of $(\mathrm{SiO})_{3} \mathrm{SiH}$ to $(\mathrm{SiO})_{3} \mathrm{SiOH}$ and condensation of asformed $\mathrm{Q}^{3}$ silanols, respectively, were detected. These results provide strong evidences of the on-site reduction via host-guest redox chemistry in the porous monolith.

The formation of the supported $\operatorname{Pd}(0)$ nanoparticles in Pd@HSQ is also confirmed by HAADF-STEM measurements of the Pd@HSQ monolith as shown in Fig. 3. A broad size distribution from 50 to $1 \mathrm{~nm}$ for supported Pd nanoparticles was observed. The as-formed nanoparticles are embedded in the monolithic support by physical confinement.

\section{Catalytic performances}

The Pd@HSQ monolith was then evaluated as a catalyst for the Mizoroki-Heck coupling reaction between 4-iodotoluene and $n$ butyl acrylate (Table $1,{ }^{1} \mathrm{H}$ and ${ }^{13} \mathrm{C}$ NMR spectra of all the products are given in ESI†). In order to achieve the highest catalytic activity, conversion and yield, the reaction condition was initially optimized by means of changing catalyst loading, base, solvent and reaction temperature. The catalytic activity in the coupling reaction was low in the presence of $2 \mathrm{~mol} \%$ catalyst and triethylamine (TEA) as base at $100{ }^{\circ} \mathrm{C}$ (Entry 1). Interestingly, changes in base and solvent from TEA to $\mathrm{K}_{2} \mathrm{CO}_{3}$ and from acetonitrile to DMF, respectively, improved the catalytic performance of Pd@HSQ. The turnover frequency (TOF, mole amount of converted reactant molecules in $1 \mathrm{~h}$ per mole of catalyst) value was $1.0 \times 10 \mathrm{~h}^{-1}$ at reaction temperature of $100{ }^{\circ} \mathrm{C}$ (Entry 2). A decrease in catalyst loading to 0.5 mol \% under the identical reaction condition yields a slight higher TOF value with the Pd@HSQ catalyst (Entry 3). Reaction temperature takes a crucial part in increasing the reactivity of the catalyst in most of the cases. Indeed, an increase in reaction temperature from 100 to $130{ }^{\circ} \mathrm{C}$ while maintaining other reaction parameters constant, results in a jump of TOF value from $1.4 \times 10$ to $1.0 \times 10^{2} \mathrm{~h}^{-1}$.

We then examined versatility of the Pd@HSQ catalyst in cross-coupling of various aryl halides and $n$-butyl acrylate. Results are summarized in Table 2; all the reactions were performed under an optimized reaction condition to achieve the maximum catalytic activity. The reaction rate and catalytic activities are not influenced by electronic properties of the substituents on the aromatic ring of the starting material. Highly electron donating substituent such as 4-methoxy (Entry 7) and4-amino (Entry 8) do not change the catalytic activity. Similar results were obtained with electron withdrawing substituents such as 4-nitro (Entry 10), 4-acetate (Entry 11). Functional groups with weak donating/withdrawing properties like 4-bromo (Entry 12), 4-ethyl acetate (Entry 13), 3-methoxy (Entry 9) and 3-methyl (Entry 6) groups naturally do not change the reactivity.

In order to investigate effects of the kind of halogen substituents on the coupling reaction, we also tested bromo- and chloro-derivative aromatics with $n$-butyl acrylate. A lower catalytic performance was obtained for the coupling reaction of 4-bromotoluene (Entry 14) compared to 4-iodotoluene (Entry 4). Interestingly, a slight increase in catalytic activity was observed while performing the reaction with highly deactivated

Table 1 Conditions of the Mozoroki-Heck cross-coupling reaction of 4-iodotoluene and $n$-butyl acrylate.

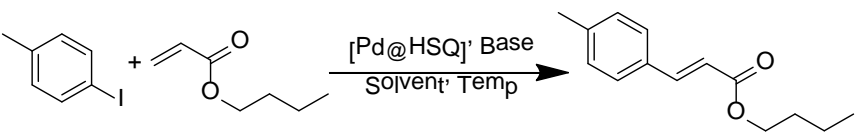

\begin{tabular}{|c|c|c|c|c|c|c|c|c|}
\hline Entry & $\begin{array}{c}\mathrm{Pd} \\
\text { mol \% in } \\
\text { Pd@HS } \\
\text { Q }\end{array}$ & Base & Solvent & $\begin{array}{l}\text { Temperature } \\
{ }^{\circ} \mathrm{C}\end{array}$ & $\begin{array}{c}\text { Reaction } \\
\text { time } \\
/ \mathrm{h}\end{array}$ & $\begin{array}{c}\text { Conversion } \\
\text { /\% }\end{array}$ & $\begin{array}{c}\text { Yield } \\
/ \%\end{array}$ & $\begin{array}{l}\text { TOF } \\
/ h^{-1}\end{array}$ \\
\hline 1 & 2.0 & TEA, 2 eq & $\mathrm{CH}_{3} \mathrm{CN}$ & 100 & 72 & 73 & 69 & $5.1 \times 10^{-1}$ \\
\hline 2 & 1.0 & $\begin{array}{c}\mathrm{K}_{2} \mathrm{CO}_{3}, 2 \\
\mathrm{eq}\end{array}$ & DMF & 100 & 10 & 100 & 98 & $1.0 \times 10$ \\
\hline 3 & 0.5 & $\begin{array}{c}\mathrm{K}_{2} \mathrm{CO}_{3}, 2 \\
\mathrm{eq}\end{array}$ & DMF & 100 & 14 & 100 & 98 & $1.4 \times 10$ \\
\hline 4 & 0.5 & $\begin{array}{c}\mathrm{K}_{2} \mathrm{CO}_{3}, 2 \\
\mathrm{eq}\end{array}$ & DMF & 130 & 2 & 100 & 99 & $1.0 \times 10^{2}$ \\
\hline
\end{tabular}




\section{ARTICLE}

Table 2 The Mizoroki-Heck cross-coupling reaction of various aryl halides and $n$-butyl acrylate catalyzed by Pd@HSQ

\begin{tabular}{|c|c|c|c|c|c|c|c|c|}
\hline Entry & $\mathrm{R}$ & $\mathrm{X}$ & $\begin{array}{c}\text { Reaction } \\
\text { time } \\
/ \mathrm{h}\end{array}$ & $\begin{array}{c}\text { Conversion } \\
/ \%\end{array}$ & $\begin{array}{c}\text { Yield } \\
/ \%\end{array}$ & $\begin{array}{l}\text { TOF } \\
/ h^{-1}\end{array}$ & Entry & $\mathrm{R}$ \\
\hline 5 & $\mathrm{H}$ & I & 2 & 100 & 99 & $1.0 \times 10^{2}$ & 5 & $\mathrm{H}$ \\
\hline 6 & 3-Me & I & 2 & 100 & 99 & $1.0 \times 10^{2}$ & 6 & 3-Me \\
\hline 7 & $4-\mathrm{MeO}$ & I & 2 & 100 & 98 & $1.0 \times 10^{2}$ & 7 & $4-\mathrm{MeO}$ \\
\hline 8 & 4-NH2 & I & 2 & 100 & 99 & $1.0 \times 10^{2}$ & 8 & 4-NH2 \\
\hline 9 & 3-MeO & I & 2 & 100 & 99 & $1.0 \times 10^{2}$ & 9 & 3-MeO \\
\hline 10 & 4-NO2 & I & 2 & 100 & 98 & $1.0 \times 10^{2}$ & 10 & 4-NO2 \\
\hline 11 & 4-Ac & I & 2 & 100 & 98 & $1.0 \times 10^{2}$ & 11 & 4-Ac \\
\hline 12 & $4-\mathrm{Br}$ & I & 2 & 100 & 97 & $1.0 \times 10^{2}$ & 12 & $4-\mathrm{Br}$ \\
\hline 13 & 4-COOEt & I & 2 & 100 & 97 & $1.0 \times 10^{2}$ & 13 & 4-COOEt \\
\hline 14 & 4-Me & $\mathrm{Br}$ & 48 & 16 & 15 & $6.7 \times 10^{-1}$ & 14 & 4-Me \\
\hline 15 & $4-\mathrm{NO}_{2}$ & $\mathrm{Br}$ & 14 & 82 & 80 & $1.2 \times 10$ & 15 & $4-\mathrm{NO}_{2}$ \\
\hline 16 & 4-Me & $\mathrm{Cl}$ & 48 & 0 & 0 & 0 & 16 & 4-Me \\
\hline
\end{tabular}

4-nitrobromobenzene (Entry 15). A further increase in electronegativity of the halogen substituent from bromo to chloro (Entry 16) inhibits the proceeding of $\mathrm{C}-\mathrm{C}$ coupling due to lower reactivity, demonstrating the limitation of the Pd@HSQ catalyst. ${ }^{37-39}$

In addition to the catalytic properties investigated above, environmental advantages such as recyclability/reusability have to be taken into consideration to develop as a practical catalyst material. Reusability of the Pd@HSQ was therefore investigated using the previously mentioned model reaction. As the catalyst is embedded in the monolith, recovery tests were performed just by taking out the Pd@HSQ from the reaction mixture, washing with solvents and drying at $40{ }^{\circ} \mathrm{C}$, and then the monolith was subjected to the next cycle. The reusability tests for ten times did not show any indication of a decrease in the catalytic activity; the TOF values of $1.0 \times 10^{2} \mathrm{~h}^{-1}$ were almost unchanged at all cycle numbers (Fig. 4a). Moreover, elemental analysis of the product showed no indication of leaching of $\mathrm{Pd}$, which is particularly important for preserving the catalytic activity of Pd@HSQ. A detailed characterization of the recovered catalyst after ten repetitions was performed. A preservation of macroporous co-continuous structure was observed in the SEM image of the Pd@HSQ repetitively used for 10 times (Fig. 5b). A preservation of Pd nanoparticles in its complete loading and entirety as well as unchanged average particle size was demonstrated by XRD measurements; diffraction patterns including the peak heights and widths are almost the same before and after the 10-time reuses (Fig. 4c). A slight decrease of specific surface area after reusing for 10 times is attributed to a slight increase in specific weight due to the oxidation of the HSQ support in the course of reusing (Fig. 4d and Fig. S3, ESI†).

All of these test results clearly demonstrate an excellent catalytic performance in terms of activity, stability, reusability a.
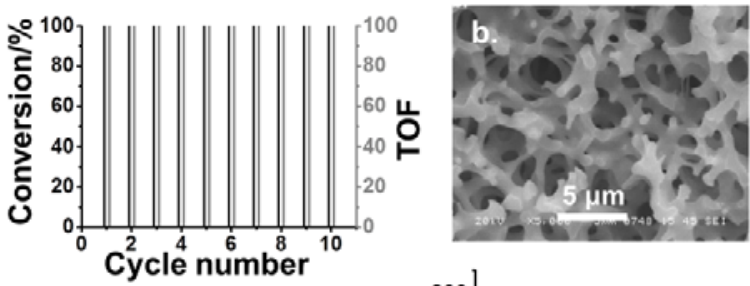

C.
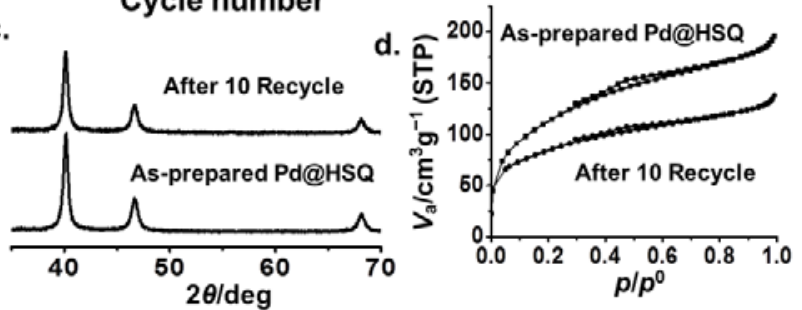

Fig. 4 Reusability test results of the Pd@HSQ catalyst. (a) Conversion versus cycle number of the Pd@HSQ for 10 consecutive cycles. (b) SEM image of the Pd@HSQ after 10time reuses. (c) XRD patterns of the Pd@HSQ before and after 10-time reuses. (d) Nitrogen adsorption-desorption isotherms of Pd@HSQ before and after 10-time reuses.

and robustness. The new Pd@HSQ monoliths can be prepared and used by the facile processes and can be used for many times without deteriorating catalytic activity and the porous structure. It can be concluded that the newly developed Pd@HSQ catalyst is one of the ideal catalysts for C-C crosscoupling reactions.

\section{Experimental}

Synthesis of HSQ monolith 
The HSQ monolith with well-defined macroporous structure was synthesized by the previously published procedure with some modifications. In short, to $25 \mathrm{ml}$ of a $1: 1$ (in volume) mixture of $\mathrm{MeOH}$ and $0.05 \mathrm{M} \mathrm{HNO}_{3} \mathrm{aq}, 1.05 \mathrm{~g}$ of $\mathrm{PEO}$ with number average molecular weight of 35,000 was added and stirred at room temperature for $30 \mathrm{~min}$ to dissolve completely. To this mixture was added $10.50 \mathrm{~mL}$ of HTMS and stirred for 2 min for hydrolysis. After stopping stirring, the resultant transparent solution was transferred to a cylindrical tube with diameter of $5.5 \mathrm{~mm}$ and length of $225 \mathrm{~mm}$, and left at room temperature for gelation. Gelation occurred in $15 \mathrm{~min}$, and the as-formed gel was aged at room temperature for $24 \mathrm{~h}$. The column shaped gel was taken out from the tube and washed with methanol ( 3 times, $8 \mathrm{~h}$ for each time). It was then dried at $40^{\circ} \mathrm{C}$ for $12 \mathrm{~h}$ in air.

\section{Synthesis of Pd@HSQ}

Typically, $50 \mathrm{mg}$ ( $\sim 5 \mathrm{~mm}$ length $5.5 \mathrm{~mm}$ diameter) of assynthesized HSQ was immersed in $5 \mathrm{~mL}$ of distilled water, and $0.2 \mathrm{~mL}$ of $50 \mathrm{mM} \mathrm{PdCl}_{2}(0.01 \mathrm{mmol} \mathrm{Pd})$ solution was added to this mixture. The solution was allowed to stand for $3 \mathrm{~h}$ at room temperature. The monolith was then taken out of the solution and solvent-exchanged with methanol followed by drying at $40{ }^{\circ} \mathrm{C}$ for $12 \mathrm{~h}$.

\section{Catalyst performances}

The as-synthesized Pd@HSQ containing different amounts (0-2.0 mol \% relative to the substrate) of Pd nanoparticles was dipped in a solution containing aromatic halide (2 mmol), $n$ butyl acrylate ( $3 \mathrm{mmol}$ ) and a base (TEA or $\mathrm{K}_{2} \mathrm{CO}_{3}, 4 \mathrm{mmol}$ ) in DMF. The mixture was allowed to stand at desired temperature. After completion of the reaction, the mixture was cooled to room temperature and the monolithic catalyst was taken out. The reaction was quenched by an addition of water, followed by extraction with diethyl ether. The organic layer was dried over $\mathrm{MgSO}_{4}$ and evaporated to obtain the crude product, which was then purified by silica gel column chromatography.

\section{Characterizations}

Microstructures of the fractured surfaces of the samples were observed under a scanning electron microscope (JSM-6060S, JEOL Ltd. (Japan)). Macropore size and volume in the samples were characterized by using a mercury porosimeter (Pore Master 60-GT, Quantachrome Instruments (USA)). The mesoand micropores present in the samples were analyzed by nitrogen adsorption-desorption measurements (BELSORP-mini II, BEL Japan, Inc. (Japan)). The samples were degassed at $200{ }^{\circ} \mathrm{C}$ for $6 \mathrm{~h}$ before each measurement. Solid-state ${ }^{29} \mathrm{Si}$ single pulse NMR experiment was performed on an OPENCORE $\mathrm{NMR}^{40,41}$ at $299.52 \mathrm{MHz}$ (for ${ }^{1} \mathrm{H}$ ) with a contact time of $10 \mathrm{~ms}$ using a 5-mm probe at $5 \mathrm{kHz}$. The X-ray diffraction patterns of the Pd@HSQ were recorded by a powder X-ray diffractometer (RINT Ultima III, Rigaku Corp. (Japan)) using $\mathrm{Cu} \mathrm{K \alpha}(\lambda=$ $0.154 \mathrm{~nm}$ ) as an incident beam. To characterize the size of the Pd nanoparticles and their spatial distributions within the monoliths, high angle annular dark-field (HAADF)-scanning transmission electron microscopy (STEM) was employed. The composite powder samples were settled on a Cu-grid after grinding the bulk samples and were examined by $Z$-contrast HAADF-STEM. The high-resolution TEM JEM-2100F (JEOL Ltd. (Japan)) was operated at $200 \mathrm{kV}$ with an STEM unit equipped with a spherical-aberration corrector (CEOS GmbH (Germany)), which provides a minimum probe of about $0.1 \mathrm{~nm}$ in diameter. During HAADF-STEM imaging, a probe convergence angle of 25 mrad and an annular dark-field detector with an inner angle higher than 52 mrad were used. Liquid-state ${ }^{1} \mathrm{H}$ and ${ }^{13} \mathrm{C}$ NMR measurements were performed using an ECX-400 spectrometer (JEOL Ltd. (Japan)) in CDCl 3 .

\section{Conclusions}

A single-step, three-hour process for synthesizing Pd nanoparticles-embedded HSQ monoliths using an on-site reduction methodology is demonstrated. This methodology is based on host-guest redox consisting of reduction of $\mathrm{Pd}^{2+}$ to $\mathrm{Pd}(0)$ and oxidation of $\mathrm{Si}-\mathrm{H}$ to $\mathrm{Si}-\mathrm{O} \sim$ in aqueous solution. The nanoparticles reduced in hierarchically porous HSQ are simultaneously immobilized (confined) in the HSQ host with preservation of its microstructure, making it a suitable material for catalytic applications. Quantitative reduction of $\mathrm{Pd}^{2+}$ to $\operatorname{Pd}(0)$ is advantageous to change the catalyst loading just by treating with a different amount of metal salt. The average Pd particle size of $20 \mathrm{~nm}$ is confirmed by XRD and HAADFSTEM, and the access of reactants to the catalytic sites is facilitated through its open pore architecture. The assynthesized Pd@HSQ monolith was then subjected to the Mizoroki-Heck cross-coupling reaction, in which diverse kinds of aromatic halides were tested to examine the applicability of the catalyst. Regardless of the substituent groups in aromatic iodides, very high catalytic activity is confirmed in the model reactions. A decrease in catalytic activity was, however, observed with increasing electronegativity of the halogen substituent.

Facile recovery and excellent reusability of the Pd@HSQ catalyst are confirmed by undetectable leaching of the catalyst form the monolith and unchanged catalytic activity even after 10 repetitive uses. This feature is made possible by multiple factors such as the facile access of reactants to the catalytic sites, physical confinement of the nanoparticles in the mesoand micropores and the preservation of meso- and miroporosity of the Pd@HSQ even after 10-time reuses. With conceivable scalability, these results suggest high potential of the Pd@HSQ catalyst in various organic reactions even in industrial scales.

\section{Acknowledgements}

The present work was financially supported by the Advanced Low Carbon Technology Research and Development Program (ALCA) from the Japan Science and Technology Agency (JST), and by a research grant from The Kyoto Technoscience Center.

\section{Notes and references}

${ }^{a}$ Department of Chemistry, Graduate school of Science, Kyoto University, Kitashirakawa, Sakyo-ku, Kyoto 606-8502, Japan. Tel \& Fax: +81-75753-7673. E-mail: kanamori@kuchem.kyoto-u.ac.jp (K.K.) and kazuki@kuchem.kyoto-u.ac.jp (K.N.)

${ }^{b}$ Department of Chemical Engineering, Nara National College of Technology, 22 Yata-cho, Yamatokoriyama, Nara 639-1080, Japan. Tel \& Fax: +81-743-55-6454. E-mail: shimada@chem.nara-k.ac.jp (T. S.)

c Japan Fine Ceramics Center, 2-4-1 Mutsuno, Atsuta-ku, Nagoya 4568587, Japan.

†Electronic Supplementary Information (ESI) available: Characterizations of the original HSQ monolith, FT-IR of materials, NMR of isolated compounds. See DOI: 10.1039/b000000x/

1 F. Diederich and P. J. Stang, in Metal-Catalyzed Cross-Coupling Reactions. Wiley-VCH, New York, 1998. 
2 E.-I. Negishi and A. de Meijere, in Handbook of Organopalladium Chemistry for Organic Synthesis. Wiley-VCH, New York, 2002.

3 S. J. Danishefsky, J. J. Masters, W. B. Young, J. T. Link, L. B. Snyder, T. V. Magee, D. K. Jung, R. C. A. Isaacs, W. G. Bornmann, C. A. Alaimo, C. A. Coburn and M. J. DiGrandi, J. Am. Chem. Soc. 1996, 118, 2843.

4 K. C. Nicolaou and E. J. Sorensen, in Classics in Total Synthesis. Wiley-VCH, New York, 1996.

5 J. Magano and J. R. Dunetz, Chem. Rev. 2011, 111, 2177.

6 K. C. Nicolaou, P. G. Bulger and D. Sarlah, Angew. Chem. Int. Ed. 2005, 44, 4442.

7 L. F. Tietze, G. Kettschau, U. Heuschert and G. Nordmann, Chem. Eur. J. 2001, 7, 368.

8 A. Balanta, C. Godard and C. Claver, Chem. Soc. Rev. 2011, 40, 4973.

9 C. Burda, X. B. Chen, R. Narayanan and M. A. El-Sayed, Chem. Rev. 2005, 105, 1025.

10 L. S. Ott and R. G. Finke, Coord. Chem. Rev. 2007, 251, 1075.

11 J. M. Campelo, D. Luna, R. Luque, J. M. Marinas and A. A. Romero, ChemSusChem 2009, 2, 18.

12 M. Stratakis and H. Garcia, Chem. Rev. 2012, 112, 4469.

13 N. G. Willis and J. Guzman, Appl. Catal. A: Gen. 2008, 339, 68.

14 R. A. Sheldon, J. Chem. Technol. Biotechnol. 1997, 68, 381.

15 J. L. Shi, Chem. Rev. 2013, 113, 2139.

16 V. Polshettiwar, R. Luque, A. Fihri, H. B. Zhu, M. Bouhrara and J. M. Bassett, Chem. Rev. 2011, 111, 3036.

17 C. A. McNamara, M. J. Dixon and M. Bradley, Chem. Rev. 2002, 102, 3275.

18 D. E. De Vos, M. Dams, B. F. Sels and P. A. Jacobs, Chem. Rev. 2002, 102, 3615.

19 C. M. Crudden, M. Sateesh and R. Lewis, J. Am. Chem. Soc. 2005, 127, 10045.

20 J. Demel, S.-E. Park, J. Cejka and P. Stepnicka, Catal. Today 2008, 132, 63.

21 J. Demel, J. Cejka, S. Bakardjieva and P. Stepnicka, J. Mol. Catal. A: Chem. 2007, 263, 259.
22 J. Demel, J. Cejka, and P. Stepnicka, J. Mol. Catal. A: Chem. 2007, 274, 127.

23 Y. Zhu, S. C. Peng, A. Emi, S. Zhenshun, Monalisa and R. A. Kemp, Adv. Syn. Catal. 2007, 349, 1917.

24 V. L. Budarin, J. H. Clark, R. Luque, D. J. Macquarrie and R. J. White, Green Chem. 2008, 10, 382.

25 Z. Zhang and Z. Wang, J. Org. Chem. 2006, 71, 7485.

26 B. J. Gallon, R. W. Kojima, R. B. Kaner and P. L. Diaconescu, Angew. Chem. Int. Ed. 2007, 46, 7251.

27 D. R. Rolison, Science 2003, 299, 1698.

28 S. Ungureanu, H. Deleuze, C. Sanchez, M. I. Popa and R. Backov, Chem. Mater. 2008, 20, 6494.

29 N. Brun, P. Hesemann, G. Laurent, C. Sanchez, M. Birot, H. Deleuze and R. Backov, New J. Chem. 2013, 37, 157.

30 D. Addis, S. Das, K. Junge and M. Beller, Angew. Chem. Int. Ed. 2011, 50, 6004.

31 B. P. S. Chauhan, J. S. Rathore, M. Chauhan and A. Krawicz, J. Am. Chem. Soc. 2003, 125, 2876.

32 B. P. S. Chauhan, J. S. Rathore and T. Bandoo, J. Am. Chem. Soc. 2004, 126, 8493.

33 O. Dag, E. J. Henderson, W. Wang, J. E. Lofgreen, S. Petrov, P. M. Brodersen and G. A. Ozin, J. Am. Chem. Soc. 2011, 133, 17454.

34 N. Moitra, K. Kanamori, T. Shimada, K. Takeda, Y. H. Ikuhara, X. Gao and K. Nakanishi, Adv. Funct. Mater. 2013, 23, 2714.

35 K. Nakanishi and N. Tanaka, Acc. Chem. Res. 2007, 40, 863.

36 K. Kanamori, H. Yonezawa, K. Nakanishi, K. Hirao and H. Jinnai, J. Sep. Sci. 2004, 27, 874.

37 C. L. Deng, S. M. Guo, Y. X. Xie and J. H. Li, Eur. J. Org. Chem. 2007, 268, 1457.

38 Q. Luo, S. Eibaur and O. Reiser, J. Mol. Catal. A: Chem. 2007, 268, 65.

39 A. Corma, H. Garcia and A. Leyva, J. Catal. 2006, 240, 87.

40 K. Takeda, Rev. Sci. Instrum. 2007, 78, 033103.

41 K. Takeda, J. Magn. Reson. 2008, 192, 218. 


\section{ARTICLE}

Electronic Supplementary Information for

\section{A New Hierarchically Porous Pd@HSQ Monolithic Catalyst for Mizoroki-}

\section{Heck Cross-Coupling Reaction}

Nirmalya Moitra, ${ }^{a}$ Ayumi Matsushima, ${ }^{b}$ Toshiyuki Kamei, ${ }^{b}$ Kazuyoshi Kanamori, ${ }^{a *}$, Yumi H. Ikuhara, ${ }^{c}$ Xiang Gao, ${ }^{c}$ Kazuyuki Takeda, ${ }^{a}$ Yang Zhu, ${ }^{a}$ Kazuki Nakanishi ${ }^{a *}$ and Toyoshi Shimada ${ }^{b *}$

${ }^{a}$ Department of Chemistry, Graduate school of Science, Kyoto University, Kitashirakawa, Sakyo-ku, Kyoto 6068502, Japan.

${ }^{b}$ Department of Chemical Engineering, Nara National College of Technology, 22 Yata-cho, Yamatokoriyama, Nara 639-1080, Japan.

${ }^{c}$ Nanostructures Research Laboratory, Japan Fine Ceramics Center, 2-4-1 Mutsuno, Atsuta-ku, Nagoya 456-8587, Japan.

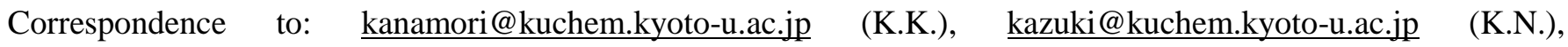
shimada@chem.nara-k.ac.jp (T.S.) 

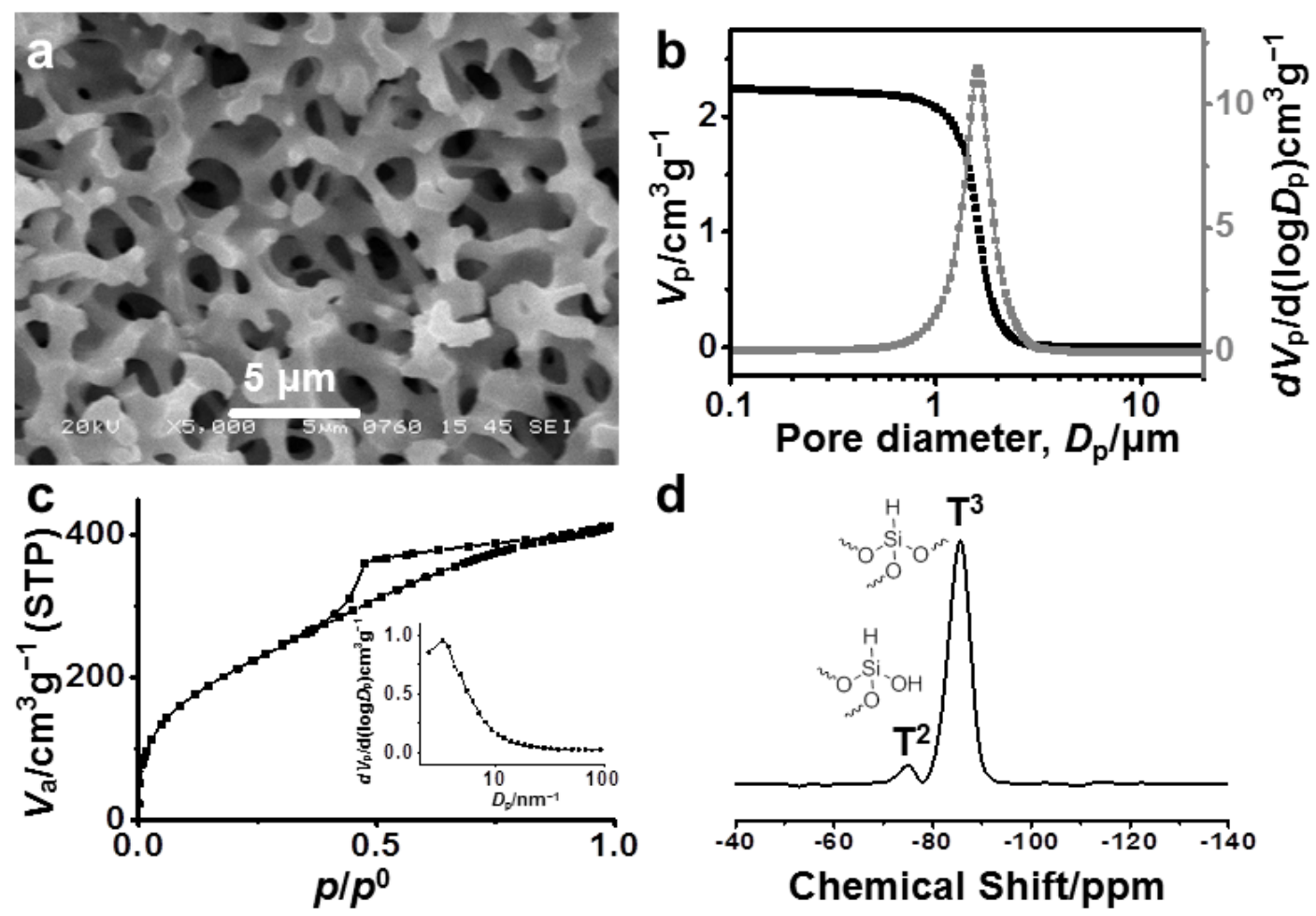

d

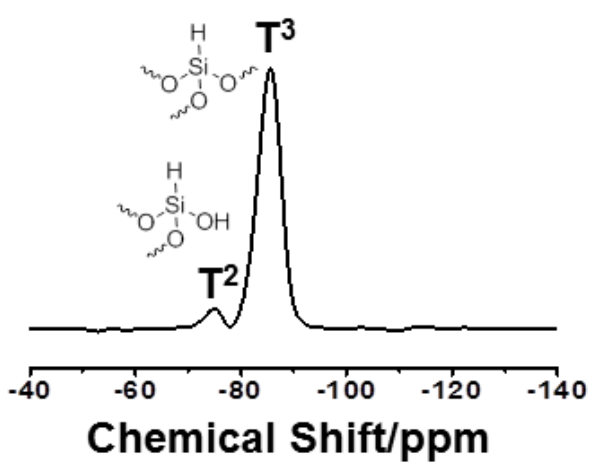

e

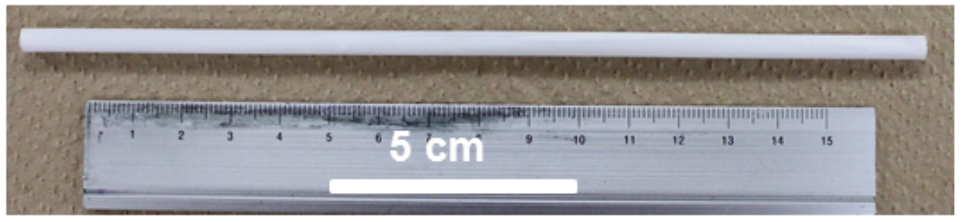

Fig. S1. Characterizations of the HSQ support. (a) SEM image of as-dried HSQ monolith, showing the presence of well-defined co-continuous macroporous structure. (b) Mercury porosimetry result, showing a sharp distribution of macropore size. (c) High specific surface area $\left(800 \mathrm{~m}^{2} / \mathrm{g}\right)$ due to the presence of small meso- and micropores was confirmed by nitrogen adsorption desorption measurement and the BJH pore size distribution curve (inset). (d) Total preservation of highly reactive Si-H bond and high condensation degree was confirmed by ${ }^{29} \mathrm{Si}$ solid-state NMR. (e) Digital camera image of the as-prepared HSQ monolith. 


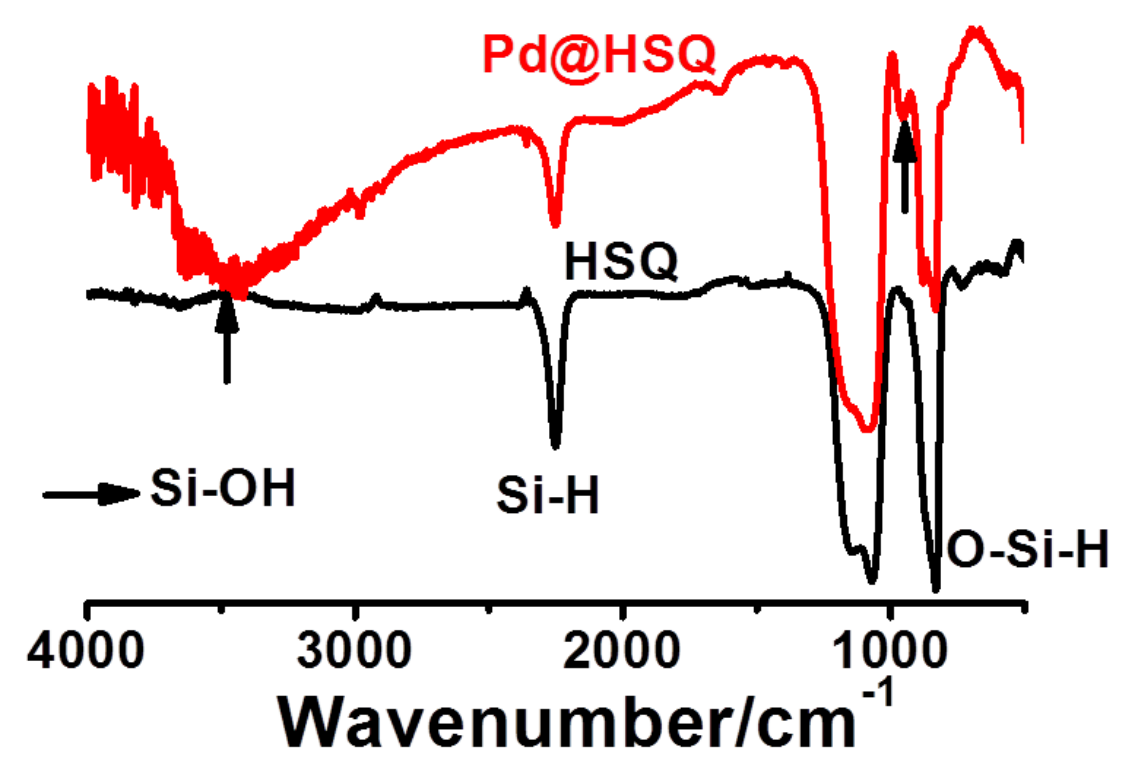

Fig. S2. FT-IR spectra showing the decreased absorption peaks of $\mathrm{Si}-\mathrm{H}$ and O-Si-H and increased absorption peaks of the Si-OH stretching vibration.

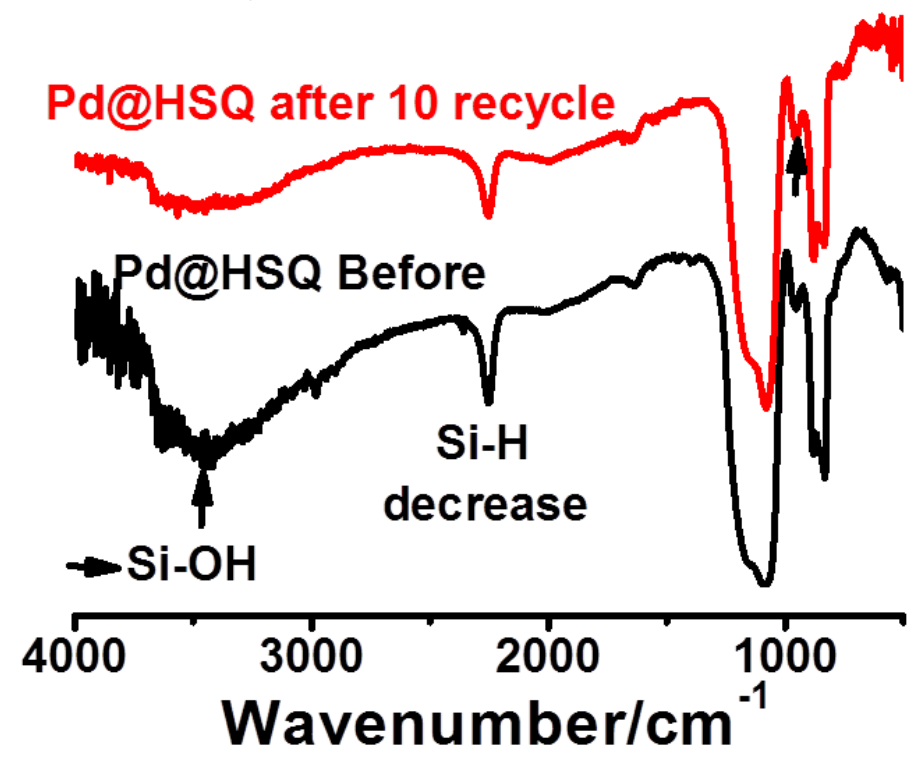

Fig. S3. FT-IR spectra of the Pd@HSQ monolith before and after 10-time reuses. The decrease in absorption by $\mathrm{Si}-\mathrm{H}$ and $\mathrm{O}-\mathrm{Si}-\mathrm{H}$ stretching vibrations suggests slight decomposition of $\mathrm{Si}-\mathrm{H}$ in the course of reuse. 


\section{${ }^{1} \mathrm{H}$ and ${ }^{13} \mathrm{C}$ NMR of the Products}

\section{Entry 4:}

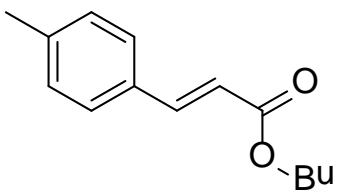

${ }^{1} \mathrm{H}$ NMR $\left(\mathrm{CDCl}_{3}\right) ; \delta=7.66(\mathrm{~d}, J=16 \mathrm{~Hz}, 1 \mathrm{H}), 7.43(\mathrm{~d}, J=8.4 \mathrm{~Hz}, 2 \mathrm{H}), 7.19(\mathrm{~d}, J=8 \mathrm{~Hz}, 2 \mathrm{H}), 6.40(\mathrm{~d}$, $J=16 \mathrm{~Hz}, 1 \mathrm{H}), 4.20$ (t, $J=6.4 \mathrm{~Hz}, 2 \mathrm{H}), 2.37$ (s, 3H), 1.64-1.74 (m, 2H), 1.38-1.50 (m, $2 \mathrm{H}), 0.97$ (t, $J=$ $7.2 \mathrm{~Hz}, 3 \mathrm{H})$.

${ }^{13} \mathrm{C}$ NMR $\left(\mathrm{CDCl}_{3}\right) ; \delta=13.70,19.24,21.39,30.72,64.27,117.19,127.97,129.53,131.65,140.54,144.50$, 167.25.

\section{Entry 5:}<smiles>CCCCOC(=O)/C=C/c1ccccc1</smiles>

${ }^{1} \mathrm{H}$ NMR $\left(\mathrm{CDCl}_{3}\right) ; \delta=7.69$ (d, $\left.J=16.4 \mathrm{~Hz}, 1 \mathrm{H}\right), 7.50-7.57$ (m, 2H), 7.36-7.43 (m, 3H), 6.45 (d, $J=16$ $\mathrm{Hz}, 1 \mathrm{H}), 4.21$ (t, $J=6.4 \mathrm{~Hz}, 2 \mathrm{H}), 1.65-1.75(\mathrm{~m}, 2 \mathrm{H}), 1.38-1.50(\mathrm{~m}, 2 \mathrm{H}), 0.97$ (t, $J=7.2 \mathrm{~Hz}, 3 \mathrm{H})$.

${ }^{13} \mathrm{C} \mathrm{NMR}\left(\mathrm{CDCl}_{3}\right) ; \delta=13.70,19.26,30.72,64.25,116.91,127.94,128.41,128.52,135.19,144.95$, 167.18.

\section{Entry 6:}<smiles>Cc1cccc(/C=C/C(=O)OCc2ccccc2)c1</smiles>

${ }^{1} \mathrm{H}$ NMR $\left(\mathrm{CDCl}_{3}\right) ; \delta=7.65(\mathrm{~d}, J=16 \mathrm{~Hz}, 1 \mathrm{H}), 7.16-7.38(\mathrm{~m}, 4 \mathrm{H}), 6.43(\mathrm{~d}, J=15.6 \mathrm{~Hz}, 1 \mathrm{H}), 4.21(\mathrm{t}, J=$ $6.8 \mathrm{~Hz}, 2 \mathrm{H}), 2.37$ (s, 3H), 1.65-1.75 (m, 2H), 1.38-1.50 (m, 2H), 0.97 (t, $J=7.2 \mathrm{~Hz}, 3 \mathrm{H})$.

${ }^{13} \mathrm{C}$ NMR $\left(\mathrm{CDCl}_{3}\right) ; \delta=13.70,19.14,21.24,30.59,64.32,117.96,125.18,128.64,128.68,130.38,130.99$, 134.34, 138.43, 144.67, 167.12 . 


\section{Entry 7:}<smiles>COc1ccc(/C=C/C(=O)OCc2ccccc2)cc1</smiles>

${ }^{1} \mathrm{H} \mathrm{NMR}\left(\mathrm{CDCl}_{3}\right) ; \delta=7.64(\mathrm{~d}, J=16 \mathrm{~Hz}, 1 \mathrm{H}), 7.48(\mathrm{~d}, J=7.2 \mathrm{~Hz}, 2 \mathrm{H}), 6.91(\mathrm{~d}, J=6.8 \mathrm{~Hz}, 2 \mathrm{H}), 6.31(\mathrm{~m}$, $J=16 \mathrm{~Hz}, 1 \mathrm{H}), 4.20$ (t, $J=6.8 \mathrm{~Hz}, 2 \mathrm{H}), 3.84$ (s, 3H), 1.64-1.74 (m, 2H), 1.38-1.50 (m, 2H), 0.97 (t, $J=$ 7.6 Hz, 3H).

${ }^{13} \mathrm{C}$ NMR $\left(\mathrm{CDCl}_{3}\right) ; \delta=13.70,19.14,30.74,55.27,64.19,114.21,115.65,127.10,129.61,144.14,161.24$, 167.38 .

\section{Entry 8:}<smiles>Nc1ccc(/C=C/C(=O)OCc2ccccc2)cc1</smiles>

${ }^{1} \mathrm{H} \mathrm{NMR}\left(\mathrm{CDCl}_{3}\right) ; \delta=7.59(\mathrm{~d}, J=16 \mathrm{~Hz}, 1 \mathrm{H}), 7.35(\mathrm{~m}, J=8.8 \mathrm{~Hz}, 2 \mathrm{H}), 6.65(\mathrm{~d}, J=8 \mathrm{~Hz}, 2 \mathrm{H}), 6.24(\mathrm{~m}$, $J=15.6 \mathrm{~Hz}, 1 \mathrm{H}), 4.18$ (t, $J=7.2 \mathrm{~Hz}, 2 \mathrm{H}), 3.94$ (br, 2H), 1.62-1.72 (m, 2H), 1.38-1.49 (m, $2 \mathrm{H}), 0.96$ (t, $J$ $=7.2 \mathrm{~Hz}, 3 \mathrm{H})$.

${ }^{13} \mathrm{C} \mathrm{NMR}\left(\mathrm{CDCl}_{3}\right) ; \delta=13.65,19.08,30.70,63.99,113.35,114.64,124.34,129.73,144.79,148.74$, 167.77 .

\section{Entry 9:}<smiles>COc1cccc(/C=C/C(=O)OCc2ccccc2)c1</smiles>

${ }^{1} \mathrm{H}$ NMR $\left(\mathrm{CDCl}_{3}\right) ; \delta=7.65(\mathrm{~d}, J=16 \mathrm{~Hz}, 1 \mathrm{H}), 7.30(\mathrm{t}, J=8.4 \mathrm{~Hz}, 1 \mathrm{H}), 7.12$ (d, $\left.J=7.6 \mathrm{~Hz}, 1 \mathrm{H}\right), 7.05$ (s, $1 \mathrm{H}), 6.94(\mathrm{~d}, J=8 \mathrm{~Hz}, 1 \mathrm{H}), 6.43$ (d, $J=16 \mathrm{~Hz}, 1 \mathrm{H}), 4.21$ (t, $J=6.8 \mathrm{~Hz}, 2 \mathrm{H}), 3.83(\mathrm{~s}, 3 \mathrm{H}), 1.65-1.75$ (m, 2H), $1.38-1.50$ (m, 2H), 0.97 (t, $J=7.2 \mathrm{~Hz}, 3 \mathrm{H})$.

${ }^{13} \mathrm{C}$ NMR $\left(\mathrm{CDCl}_{3}\right) ; \delta=13.69,19.14,30.69,55.20,64.39,112.77,116.03,118.47,120.69,129.78,135.73$, 144.41, 159.79, 166.99 . 


\section{Entry 10:}<smiles>CCCCOC(=O)/C=C/c1ccc([N+](=O)[O-])cc1</smiles>

${ }^{1} \mathrm{H} \mathrm{NMR}\left(\mathrm{CDCl}_{3}\right) ; \delta=8.25(\mathrm{~d}, J=8.8 \mathrm{~Hz}, 1 \mathrm{H}), 7.75-7.65(\mathrm{~m}, 3 \mathrm{H}), 6.57(\mathrm{~m}, J=16.4 \mathrm{~Hz}, 1 \mathrm{H}), 4.24(\mathrm{t}, J=$ $6.8 \mathrm{~Hz}, 2 \mathrm{H}), 1.65-1.75$ (m, 2H), 1.38-1.50 (m, 2H), 0.98 (t, $J=7.2 \mathrm{~Hz}, 3 \mathrm{H})$.

${ }^{13} \mathrm{C} \mathrm{NMR}\left(\mathrm{CDCl}_{3}\right) ; \delta=13.67,19.10,30.61,64.84,122.52,124.09,128.56,140.53,141.37,166.07$.

\section{Entry 11:}<smiles>O=C(/C=C/c1ccc(C(F)(F)F)cc1)O[Ga]</smiles>

${ }^{1} \mathrm{H} \mathrm{NMR}\left(\mathrm{CDCl}_{3}\right) ; \delta=7.97$ (d, $\left.J=8.4 \mathrm{~Hz}, 2 \mathrm{H}\right), 7.70$ (d, $\left.J=8.4 \mathrm{~Hz}, 1 \mathrm{H}\right), 7.61$ (d, $\left.J=8 \mathrm{~Hz}, 2 \mathrm{H}\right), 6.53(\mathrm{~d}, J$ $=16 \mathrm{~Hz}, 1 \mathrm{H}), 4.23(\mathrm{t}, J=6.8 \mathrm{~Hz}, 2 \mathrm{H}), 2.61(\mathrm{~s}, 2 \mathrm{H}), 1.65-1.75(\mathrm{~m}, 2 \mathrm{H}), 1.38-1.50(\mathrm{~m}, 2 \mathrm{H}), 0.97(\mathrm{t}, J=7.2$ $\mathrm{Hz}, 3 \mathrm{H})$.

${ }^{13} \mathrm{C}$ NMR $\left(\mathrm{CDCl}_{3}\right) ; \delta=13.62,19.05,26.56,30.77,67.53,120.68,128.00,130.31,137.80,138.66,142.83$, 166.45, 197.19 .

\section{Entry 12:}<smiles>O=C(/C=C/c1ccc(Br)cc1)O[Ga]</smiles>

${ }^{1} \mathrm{H} \mathrm{NMR}\left(\mathrm{CDCl}_{3}\right) ; \delta=7.61(\mathrm{~d}, J=16 \mathrm{~Hz}, 1 \mathrm{H}), 7.52$ (d, $\left.J=8.4 \mathrm{~Hz}, 1 \mathrm{H}\right), 7.39$ (d, $\left.J=8.4 \mathrm{~Hz}, 1 \mathrm{H}\right), 6.43$ (m, $J=16 \mathrm{~Hz}, 1 \mathrm{H}), 4.21(\mathrm{t}, J=6.8 \mathrm{~Hz}, 2 \mathrm{H}), 1.64-1.74(\mathrm{~m}, 2 \mathrm{H}), 1.37-1.49$ (m, 2H), 0.97 (t, $J=7.6 \mathrm{~Hz}, 3 \mathrm{H})$.

${ }^{13} \mathrm{C}$ NMR $\left(\mathrm{CDCl}_{3}\right) ; \delta=13.68,19.11,30.67,64.47,118.90,119.26,124.35,129.34,132.02,133.29$, 143.05, 166.72 . 


\section{Entry 13:}

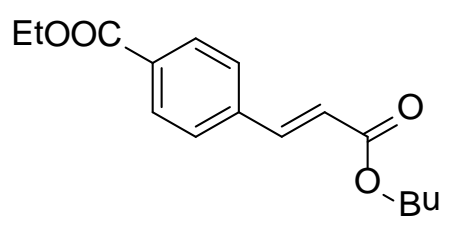

${ }^{1} \mathrm{H}$ NMR $\left(\mathrm{CDCl}_{3}\right) ; \delta=8.06$ (d, $\left.J=8 \mathrm{~Hz}, 1 \mathrm{H}\right), 7.70(\mathrm{~d}, J=16 \mathrm{~Hz}, 1 \mathrm{H}), 7.58$ (d, $\left.J=8 \mathrm{~Hz}, 1 \mathrm{H}\right), 6.52(\mathrm{~m}, J$ $=16 \mathrm{~Hz}, 1 \mathrm{H}), 4.39(\mathrm{~d}, J=6.8 \mathrm{~Hz}, 2 \mathrm{H}), 4.23(\mathrm{t}, J=6.8 \mathrm{~Hz}, 2 \mathrm{H}), 1.65-1.75(\mathrm{~m}, 2 \mathrm{H}), 1.38-1.50(\mathrm{~m}, 5 \mathrm{H})$, $0.97(\mathrm{t}, J=7.6 \mathrm{~Hz}, 3 \mathrm{H})$.

${ }^{13} \mathrm{C} \mathrm{NMR}\left(\mathrm{CDCl}_{3}\right) ; \delta=13.57,14.13,19.03,30.57,61.00,64.43,120.42,127.67,129.60,129.87,131.50$, 138.41, 142.98, 166.41 . 